\title{
STUDI EKSPLORASI PEMBIAYAAN USAHA KECIL DAN MENENGAH (UKM) DI SENTRA-SENTRA INDUSTRI KECIL DI JAWA TIMUR
}

\author{
Ely Siswanto \\ Fakultas Ekonomi Universitas Negeri Malang \\ Jl. Semarang No. 5 Malang-65145. Telepon 0341-551312 pes.552888
}

\begin{abstract}
Abstact: This research tried to explore and describe the opinion and preference of small and medium enterprises around the financing supervisory in centers of SMEs in East Java. The good description in financing and financial supervisory models would be the basic for determining the best formulation in financing and financial supervisory programs. Small and medium enterprises (SMEs) in Indonesia are developed in centers of small and medium enterprises (sentra UKM) to supervisory efectively. The centers of SMEs in this research involved Sentra Industri Mebel Kayu Pasuruan, Sentra Industri Tempe Malang, Sentra Industri Kerajinan Perak Lumajang and Sentra Industri Sandal Sepatu Mojokerto. The result of this research indicating the need for financing and financial supervisory which accommodate non financial development such as marketing, technology, and management. Furthermore, exploratory for this research indicated that there are financing and financial supervisory established in the centers known as MAP model.
\end{abstract}

Keywords: eksplorasi pembiayaan, usaha kecil dan menengah, sentra industri kecil.

Lembaga keuangan memiliki fungsi utama dalam intermediasi keuangan yakni menyalurkan dana dari pihak yang memiliki kelebihan likuiditas (unit surplus) kepada pihak yang kekurangan likuiditas (unit defisit) dalam rangka meningkatkan pertumbuhan ekonomi. Fungsi intermediasi yang diemban oleh lembaga keuangan terhadap industri kecil adalah pembiayaan dan sekaligus melakukan pembinaan manajemen baik dari sisi keuangan maupun non keuangan seperti produksi, pemasaran dan sebagainya.

Usaha kecil merupakan tulang punggung perekonomian masyarakat Indonesia. Iklim investasi yang menguntungkan, lingkungan bisnis yang kondusif serta kemudahan akses keuangan merupakan faktor utama yang dapat mengembangkan aktivitas usaha kecil. Krisis ekonomi yang memporakporandakan perekonomian nasional tahun 1997 yang lalu membangkitkan 
kesadaran pentingnya peran Usaha Kecil dan Menengah (UKM) sebagai tulang punggung perekonomian Indonesia.

Berdasarkan kriteria BPS, jumlah usaha yang ada di Indonesia tahun 2007 sebanyak 49.845.016 dan 99,99 persen di antaranya atau 49.840.489 merupakan usaha mikro, kecil dan menengah. Sementara itu, perkembangan nilai investasi usaha kecil menengah mencapai 195.048.761 juta di tahun 2007, meningkat 7,31\% dibandingkan dengan tahun 2006 yang mencapai 781.766 .970 juta. Jumlah penyerapan tenaga kerja oleh industri kecil dan menengah sebesar 91.752.318 orang atau $97,33 \%$ dari total penyerapan tenaga kerja yang ada, meningkat 2,42\% dibandingkan dengan tahun 2006 sebesar 89.547.762 orang (BPS, 2007).

Pengembangan UKM saat ini dan mendatang menghadapi berbagai hambatan dan tantangan dalam menghadapi persaingan dunia usaha yang semakin ketat. Namun demikian dengan berbagai keterbatasan yang ada, UKM masih diharapkan mampu menjadi andalan perekonomian Indonesia. Atas dasar potensi dan karakteristik tersebut, maka pemberdayaan usaha mikro, kecil dan menengah dinilai masih strategis dan sangat penting dalam mendukung perekonomian nasional. Peran strategis tersebut antara lain (Sutrisno dan Lestari, 2004): a) dengan jumlah yang sangat banyak usaha kecil berpotensi menciptakan lapangan kerja yang luas bagi masyarakat; b) kontribusi terhadap PDB menurut harga berlaku sebesar $63,11 \%$; c) usaha kecil merupakan pelaku ekonomi utama yang berinteraksi langsung dengan konsumen; d) mempunyai implikasi langsung untuk meredam persoalan-persoalan yang berdimensi sosial politik, terbukti pada waktu krisis usaha kecil menengah memegang peran kunci dalam kegiatan produksi dan distribusi.

Dalam praktiknya, masih terdapat banyak permasalahan seputar efektivitas penyaluran kredit/pembiayaan dan pembinaan oleh lembaga keuangan formal terhadap pengembangan usaha kecil baik dari sisi pengusaha kecilnya, lembaga keuangannya, maupun model pembiayaan dan pembinaannya. Kelemahan utama yang dimiliki usaha kecil cukup beragam mulai dari sisi pemasaran, produksi, maupun permodalan. Khusus kelemahan yang berhubungan dengan permodalan, kelemahan yang paling menonjol yang dimiliki sebagian besar usaha kecil adalah pengelolaan dana dan alokasi modal. (Yunus, 2007). 
Tujuan penelitian ini adalah untuk menggali dan mendeskripsikan opini dan preferensi pengusaha seputar permodalan dan pembiayaan yang diterima oleh usaha kecil dan menengan (UKM) di sentra-sentra industri kecil di Jawa Timur. Penelitian ini penting dalam rangka pengembangan usaha kecil khususnya yang berada di sentra-sentra industri kecil. Perkembangan industri kecil yang baik akan dapat meningkatkan kesejahteraan masyarakat, mengurangi pengangguran dan membuka lapangan kerja baru serta menurunkan angka kemiskinan.

\section{METODE}

Penelitian ini merupakan penelitian deskriptif eksploratif yang mencoba memberikan gambaran baik berupa data maupun opini seputar pembiayaan usaha mikro, kecil dan menengah di sentra industri kecil oleh lembaga-lembaga keuangan formal. Sampel penelitian diambil dari empat sentra unggulan di masing-masing daerah yang ada di wilayah Jawa Timur yang meliputi; (1) Sentra Industri Mebel Kayu Ukir Desa Bukir Kecamatan Gadingrejo Kota Pasuruan. (2) Sentra Industri Berbahan Baku Tempe di Dusun Sanan Kelurahan Purwantoro Kota Malang. (3) Sentra Industri Kerajinan Perak di Kecamatan Tempeh Kabupaten Lumajang. (4) Sentra Industri Sandal/Sepatu di Kota Mojokerto. Sebanyak 61 pengusaha menjadi responden penelitian ini yang meliputi 22 responden dari sentra tempe Malang, 16 responden dari sentra mebel Pasuruan, 13 responden dari sentra sandal/sepatu, dan 10 responden dari sentra perak Lumajang.

Instrumen yang digunakan dalam mengumpulkan data berupa: a) checklist yang digunakan oleh peneliti ketika melakukan observasi; b) pedoman wawancara yang digunakan untuk menggali opini dan motivasi dari para pengusaha. Teknik pengumpulkan data dengan melalui observasi, wawancara dan penelaahan dokumen dilakukan di masing-masing lokasi industri kecil dengan harapan diperoleh data tentang kondisi keuangan, penggunaan dana dan hasil atau return atas penggunaan dana.

\section{HASIL}


Berdasarkan hasil pengumpulan data diperoleh karakteristik pengusaha sampel yang meliputi jumlah aset, jumlah omset, jumlah tenaga kerja, kepemilikan pembukuan dan laporan keuangan dan sebagainya. Berdasarkan jumlah aset, sebagian besar (63,6\%) pengusaha di Sentra Industri Tempe Malang memiliki aset dibawah Rp200 juta dan selebihnya $(36,4 \%)$ tidak tahu. Sementara itu di Sentra Pasuruan sebagian besar (50\%) memiliki aset diatas Rp 200 juta dan sisanya (43,8\%) dibawah Rp 200 juta.

Kondisi tersebut tidak berbeda jauh dengan Mojokerto dimana jumlah terbesar (69,2\%) merupakan perusahaan dengan aset diatas Rp 200 juta dan 15,4\% dibawah Rp 200 juta serta sisanya tidak bersedia menjawab. Kondisi terbalik terdapat di Lumajang dimana $90 \%$ pengusaha yang menjadi sampel memiliki aset dibawah Rp 200 juta dan 10\% diatas Rp 200 juta. Secara agregat, sebagian besar $(52,5 \%)$ pengusaha memiliki aset di bawah Rp 200 juta dan sisanya $(29,5 \%)$ diatas Rp 200 juta dan 18\% tidak bersedia menjawab. Tabel 1 mendeskripsikan jumlah aset yang dimiliki UMKM sampel (Tabel 1).

Tabel 1

Klasifikasi Pengusaha Berdasarkan Jumlah Aset

\begin{tabular}{|c|c|c|c|c|c|c|c|c|c|c|c|}
\hline \multirow[t]{2}{*}{ No. } & \multirow[t]{2}{*}{ Jumlah Aset } & \multicolumn{2}{|c|}{ Malang } & \multicolumn{2}{|c|}{ Pasuruan } & \multicolumn{2}{|c|}{ Mojokerto } & \multicolumn{2}{|c|}{ Lumajang } & \multicolumn{2}{|c|}{ Total } \\
\hline & & $\mathrm{Jml}$ & $\%$ & $\mathrm{Jml}$ & $\%$ & $\mathrm{Jml}$ & $\%$ & $\mathrm{Jml}$ & $\%$ & $\mathrm{Jml}$ & $\%$ \\
\hline 1 & $<200$ juta & 14 & 63.6 & 7 & 43.8 & 2 & 15.4 & 9 & 90.0 & 32 & 52.5 \\
\hline 2 & $>200$ juta & 0 & - & 8 & 50.0 & 9 & 69.2 & 1 & 10.0 & 18 & 29.5 \\
\hline 3 & $\begin{array}{l}\text { Tidak } \\
\text { menjawab }\end{array}$ & 8 & 36.4 & 1 & 6.3 & 2 & 15.4 & 0 & - & 11 & 18.0 \\
\hline & Total & 22 & 100,0 & 16 & 100,0 & 13 & 100.0 & 10 & 100,0 & 61 & 100,0 \\
\hline
\end{tabular}

Berdasarkan jumlah omset, sebagian besar (73\%) pengusaha di Sentra Tempe Sanan memiliki omset penjualan di bawah Rp1 miliar pertahun. Di Pasuruan, pengusaha mebel sebagaian besar (69\%) mencatatatkan omset diatas Rp1 miliar dan 25\% di bawah Rp1 miliar. Di Mojokerto kondisinya sedikit berbeda dengan Pasuruan yakni sebagian besar (92\%) pengusaha memilliki omset diatas 1 sampai 10 miliar 8\% dibawah Rp1 miliar. Sementara itu, sebagian besar (90\%) pengusaha di sentra perak Lumajang secara agregat, sebagian besar (46\%) pengusaha merupakan usaha kecil dengan omset dibawah 1 miliar setahun. Sebesar 42,6\% merupakan usaha menengah dengan omset antara 1 sampai 10 
Miliar setahun, dan sisanya $(11,5 \%)$ tidak bersedia memberikan jawaban (Tabel 2).

Tabel 2

\section{Klasifikasi Pengusaha Berdasarkan Jumlah Omset}

Tabel 2 Klasifikasi Pengusaha Berdasarkan Jumlah Omset

\begin{tabular}{|c|c|c|c|c|c|c|c|c|c|c|c|}
\hline \multirow[t]{2}{*}{ No. } & \multirow{2}{*}{$\begin{array}{c}\text { Jumlah } \\
\text { Omset } \\
\text { pertahun }\end{array}$} & \multicolumn{2}{|c|}{ Malang } & \multicolumn{2}{|c|}{ Pasuruan } & \multicolumn{2}{|c|}{ Mojokerto } & \multicolumn{2}{|c|}{ Lumajang } & \multicolumn{2}{|c|}{ Total } \\
\hline & & $\mathrm{Jml}$ & $\%$ & $\mathrm{Jml}$ & $\%$ & $\mathrm{Jml}$ & $\%$ & $\mathrm{Jml}$ & $\%$ & $\mathrm{Jml}$ & $\%$ \\
\hline 1 & $<1 \mathrm{M}$ & 16 & 72.7 & 11 & 68.8 & 1 & 7.7 & 0 & - & 28 & 45.9 \\
\hline 2 & $1 \mathrm{M}-10 \mathrm{M}$ & 0 & - & 4 & 25.0 & 12 & 92.3 & 10 & 100.0 & 26 & 42.6 \\
\hline 3 & $>10 \mathrm{M}$ & 0 & - & 0 & - & 0 & - & 0 & - & 0 &  \\
\hline 4 & $\begin{array}{l}\text { Tidak } \\
\text { menjawab }\end{array}$ & 6 & 27.3 & 1 & 6.3 & 0 & - & 0 & - & 7 & 11.5 \\
\hline & Total & 22 & 100,0 & 16 & 100,0 & 13 & 100.0 & 10 & 100,0 & 61 & 100.0 \\
\hline
\end{tabular}

Kendala yang dihadapi pengusaha secara umum dikelompokkan kedalam kendala terkait keuangan, pemasaran dan proses produksi. Secara agregat, kendala keuangan merupakan merupakan kendala terbesar (46\%) yang dihadapi pengusaha dan sisanya (28\%) adalah kendala pemasaran sedangkan kendala produksi tidak terpaut jauh dengan pemasaran yakni $25 \%$. Kondisi ini tidaklah seragam diantara masing-masing sentra. Di Malang, Pasuruan dan Mojokerto, sebagian besar kendala dalam hal keuangan, sedangkan di Lumajang, kendala terbesar adalah dalam hal pemasaran (Tabel 3).

Tabel 3

Kendala Utama yang dihadapi Pengusaha

\begin{tabular}{llrrrrrrrrrrrr}
\hline No. & Kendala & \multicolumn{2}{c}{ Malang } & \multicolumn{2}{c}{ Pasuruan } & \multicolumn{2}{c}{ Mojokerto } & \multicolumn{2}{c}{ Lumajang } & \multicolumn{2}{c}{ Total } \\
\cline { 2 - 13 } & Utama & Jml & $\%$ & Jml & $\%$ & Jml & $\%$ & Jml & $\%$ & Jml & $\%$ \\
\hline 1 & Kendala & 0 & - & 5 & 31.3 & 2 & 15.4 & 10 & 100.0 & 17 & 27.9 \\
& $\begin{array}{l}\text { Pemasaran } \\
2\end{array}$ & & & & & & & & & & \\
\hline & $\begin{array}{l}\text { Kendala } \\
\text { Produksi }\end{array}$ & 7 & 31.8 & 3 & 18.8 & 5 & 38.5 & 0 & - & 15 & 24.6 \\
\hline 3 & $\begin{array}{l}\text { Kendalan } \\
\text { Keuangan }\end{array}$ & 15 & 68.2 & 7 & 43.8 & 6 & 46.2 & 0 & - & 28 & 45.9 \\
& Tidak ada & 0 & - & 1 & 6.3 & 0 & - & 0 & - & 1 & 1.6 \\
\hline 4 & Total & 22 & 100,0 & 16 & 100,0 & 13 & 100,0 & 10 & 100,0 & 61 & 100,0 \\
\hline
\end{tabular}


Dalam hal pemasaran, secara agregat, sebesar $26 \%$ pengusaha mengalami masalah akses pasar, $21 \%$ masalah jalur distribusi dan $15 \%$ kesulitan promosi (Tabel 4).

Tabel 4

Kendala Utama dalam Hal Pemasaran

\begin{tabular}{|c|c|c|c|c|c|c|c|c|c|c|c|}
\hline \multirow[t]{2}{*}{ No. } & \multirow{2}{*}{$\begin{array}{l}\text { Kendala } \\
\text { Utama }\end{array}$} & \multicolumn{2}{|c|}{ Malang } & \multicolumn{2}{|c|}{ Pasuruan } & \multicolumn{2}{|c|}{ Mojokerto } & \multicolumn{2}{|c|}{ Lumajang } & \multicolumn{2}{|c|}{ Total } \\
\hline & & $\mathrm{Jml}$ & $\%$ & $\mathrm{Jml}$ & $\%$ & $\mathrm{Jml}$ & $\%$ & $\mathrm{Jml}$ & $\%$ & $\mathrm{Jml}$ & $\%$ \\
\hline 1 & Akses pasar & 0 & - & 7 & 43.8 & 3 & 23.1 & 6 & 60.0 & 16 & 26.2 \\
\hline 2 & $\begin{array}{l}\text { Jalur } \\
\text { distribusi }\end{array}$ & 9 & 40.9 & 0 & - & 3 & 23.1 & 1 & 10.0 & 13 & 21.3 \\
\hline 3 & $\begin{array}{l}\text { Kesulitan } \\
\text { promosi }\end{array}$ & 0 & - & 3 & 18.8 & 3 & 23.1 & 3 & 30.0 & 9 & 14.8 \\
\hline 4 & $\begin{array}{l}\text { Lainnya } \\
\text { (tidak ada) }\end{array}$ & 13 & 59.1 & 6 & 37.5 & 4 & 30.8 & 0 & - & 23 & 37.7 \\
\hline & Total & 22 & 100,0 & 16 & 100,0 & 13 & 100,0 & 10 & 100,0 & 61 & 100,0 \\
\hline
\end{tabular}

Permasalahan dalam bidang produksi, secara agregat tingginya biaya produksi merupakan permasalahan utama para pengusaha dengan $67 \%$. Sedangkan $11 \%$ menganggap bahan mentah merupakan permasalahan utam dan $5 \%$ ketertinggalan teknologi (Tabel 5).

Tabel 5

Kendala Utama dalam Hal Produksi

\begin{tabular}{|c|c|c|c|c|c|c|c|c|c|c|c|}
\hline \multirow[t]{2}{*}{ No. } & \multirow{2}{*}{$\begin{array}{c}\text { Kendala } \\
\text { Utama }\end{array}$} & \multicolumn{2}{|c|}{ Malang } & \multicolumn{2}{|c|}{ Pasuruan } & \multicolumn{2}{|c|}{ Mojokerto } & \multicolumn{2}{|c|}{ Lumajang } & \multicolumn{2}{|c|}{ Total } \\
\hline & & $\mathrm{Jml}$ & $\%$ & $\mathrm{Jml}$ & $\%$ & $\mathrm{Jml}$ & $\%$ & $\mathrm{Jml}$ & $\%$ & $\mathrm{Jml}$ & $\%$ \\
\hline \multirow[t]{2}{*}{1} & Kesulitan & 0 & - & 4 & 25.0 & 3 & 23.1 & 0 & - & 7 & 11.5 \\
\hline & Bahan Mentah & & & & & & & & & & \\
\hline \multirow[t]{2}{*}{2} & Ketertinggalan & 0 & - & 0 & - & 3 & 23.1 & 0 & - & 3 & 4.9 \\
\hline & Teknologi & & & & & & & & & & \\
\hline \multirow[t]{3}{*}{3} & Biaya & 22 & 100.0 & 4 & 25.0 & 5 & 38.5 & 10 & 100.0 & 41 & 67.2 \\
\hline & produksi & & & & & & & & & & \\
\hline & tinggi & & & & & & & & & & \\
\hline \multirow[t]{3}{*}{4} & Lainnya (tidak & 0 & - & 8 & 50.0 & 2 & 15.4 & 0 & - & 10 & 16.4 \\
\hline & ada) & & & & & & & & & & \\
\hline & Total & 22 & 100,0 & 16 & 100,0 & 13 & 100,0 & 10 & 100,0 & 61 & 100,0 \\
\hline
\end{tabular}




\section{Kendala Utama yang dihadapi Pengusaha dalam Bidang Keuangan}

Kendala dalam bidang keuangan adalah kendala-kendala terkait dengan perolehan modal, pengelolaan modal, serta kepemilikan pembukuan dan laporan keuangan. Khusus berkaitan dengan pengelolaan keuangan, secara agregat, permasalahan perolehan modal masih mendominasi dengan prosentase $41 \%, 25 \%$ permasalahan pencatatan dan $5 \%$ permasalahan pengelolaan modal dan $26 \%$ merasa tidak ada masalah dengan keuangan (Tabel 6).

\section{Tabel 6}

Kendala Utama dalam Hal Keuangan

\begin{tabular}{|c|c|c|c|c|c|c|c|c|c|c|c|}
\hline \multirow[t]{2}{*}{ No. } & \multirow{2}{*}{$\begin{array}{c}\text { Kendala } \\
\text { Utama }\end{array}$} & \multicolumn{2}{|c|}{ Malang } & \multicolumn{2}{|c|}{ Pasuruan } & \multicolumn{2}{|c|}{ Mojokerto } & \multicolumn{2}{|c|}{ Lumajang } & \multicolumn{2}{|c|}{ Total } \\
\hline & & $\mathrm{Jml}$ & $\%$ & $\mathrm{Jml}$ & $\%$ & $\mathrm{Jml}$ & $\%$ & $\mathrm{Jml}$ & $\%$ & $\mathrm{Jml}$ & $\%$ \\
\hline 1 & $\begin{array}{l}\text { Kesulitan } \\
\text { memperoleh } \\
\text { modal }\end{array}$ & 13 & 59.1 & 5 & 31.3 & 7 & 53.8 & 0 & - & 25 & 41.0 \\
\hline 2 & $\begin{array}{l}\text { Kesulitan } \\
\text { mengelola } \\
\text { modal }\end{array}$ & 0 & - & 2 & 12.5 & 3 & 23.1 & 0 & - & 5 & 8.2 \\
\hline 3 & $\begin{array}{l}\text { Kesulitan } \\
\text { melakukan } \\
\text { pencatatan }\end{array}$ & 5 & 22.7 & 7 & 43.8 & 2 & 15.4 & 1 & 10.0 & 15 & 24.6 \\
\hline 4 & $\begin{array}{l}\text { Lainnya } \\
\text { (tidak ada) }\end{array}$ & 4 & 18.2 & 2 & 12.5 & 1 & 7.7 & 9 & 90.0 & 16 & 26.2 \\
\hline & Total & 22 & 100,0 & 16 & 100,0 & 13 & 100,0 & 10 & 100,0 & 61 & 100,0 \\
\hline
\end{tabular}

Sebagian besar responden (56\%) masih mengangap tingginya bunga dan jatuh tempo kredit sebagai permasalahan utama, 13\% merasakan persyaratan aplikasi kredit yang berat dan hanya $2 \%$ yang merasa kurangnya informasi kredit (Tabel 7). 
Tabel 7

Kendala Utama dalam Memperoleh Modal

\begin{tabular}{|c|c|c|c|c|c|c|c|c|c|c|c|}
\hline \multirow[t]{2}{*}{ No. } & \multirow{2}{*}{$\begin{array}{c}\text { Kendala } \\
\text { Utama }\end{array}$} & \multicolumn{2}{|c|}{ Malang } & \multicolumn{2}{|c|}{ Pasuruan } & \multicolumn{2}{|c|}{ Mojokerto } & \multicolumn{2}{|c|}{ Lumajang } & \multicolumn{2}{|c|}{ Total } \\
\hline & & $\mathrm{Jml}$ & $\%$ & $\mathrm{Jml}$ & $\%$ & $\mathrm{Jml}$ & $\%$ & $\mathrm{Jml}$ & $\%$ & $\mathrm{Jml}$ & $\%$ \\
\hline \multirow[t]{2}{*}{1} & Kurangnya & 0 & - & 0 & - & 1 & 7.7 & 0 & - & 1 & \\
\hline & informasi & & & & & & & & & & 1.6 \\
\hline \multirow[t]{2}{*}{2} & Persyaratan & 0 & - & 4 & 25.0 & 4 & 30.8 & 0 & - & 8 & \\
\hline & yang berat & & & & & & & & & & 13.1 \\
\hline \multirow[t]{3}{*}{3} & Bunga tinggi, & 16 & & 6 & 37.5 & 3 & 23.1 & 9 & 90.0 & 34 & \\
\hline & jatuh tempo & & 72.7 & & & & & & & & 55.7 \\
\hline & pendek & & & & & & & & & & \\
\hline \multirow[t]{3}{*}{4} & Lainnya & 6 & & 6 & 37.5 & 5 & 38.5 & 1 & 10.0 & 18 & \\
\hline & (tidak ada) & & 27.3 & & & & & & & & 29.5 \\
\hline & Total & 22 & 100,0 & 16 & 100,0 & 13 & 100,0 & 10 & 100,0 & 61 & 100,0 \\
\hline
\end{tabular}

Secara agregat, sebesar 38\% merasakan modal yang tidak mencukupi serta salah alokasi $8 \%$, dan sebagian besar (54\%) mengaggap tidak ada masalah dalam pengelolaan modal (Tabel 8).

\section{Tabel 8}

Kendala dalam Mengelola Modal

\begin{tabular}{|c|c|c|c|c|c|c|c|c|c|c|c|}
\hline \multirow[t]{2}{*}{ No. } & \multirow{2}{*}{$\begin{array}{c}\text { Kendala } \\
\text { Utama }\end{array}$} & \multicolumn{2}{|c|}{ Malang } & \multicolumn{2}{|c|}{ Pasuruan } & \multicolumn{2}{|c|}{ Mojokerto } & \multicolumn{2}{|c|}{ Lumajang } & \multicolumn{2}{|c|}{ Total } \\
\hline & & $\mathrm{Jml}$ & $\%$ & $\mathrm{Jml}$ & $\%$ & $\mathrm{Jml}$ & $\%$ & $\mathrm{Jml}$ & $\%$ & $\mathrm{Jml}$ & $\%$ \\
\hline 1 & $\begin{array}{l}\text { Modal tidak } \\
\text { mencukupi }\end{array}$ & 10 & 45.5 & 6 & 37.5 & 7 & 53.8 & 0 & - & 23 & 37.7 \\
\hline 2 & Salah alokasi & 1 & 4.5 & 2 & 12.5 & 1 & 7.7 & 1 & 10.0 & 5 & 8.2 \\
\hline 3 & $\begin{array}{l}\text { Lainnya } \\
\text { (tidak ada) }\end{array}$ & 11 & 50.0 & 8 & 50.0 & 5 & 38.5 & 9 & 90.0 & 33 & 54.1 \\
\hline & Total & 22 & 100,0 & 16 & 100,0 & 13 & 100,0 & 10 & 100,0 & 61 & 100,0 \\
\hline
\end{tabular}

Sekitar $84 \%$ pengusaha di sentra-sentra industri kecil tidak memiliki pembukuan, hanya $16 \%$ yang memiliki pembukuan sederhana. Kondisi ini relatif seragam di hampir seluruh sentra yang dijadikan sampel. Di Malang hanya 9\% yang memiliki pembukuan, di Pasuruan 25\%, Mokojerto 23\% dan Lumajang $10 \%$ yang memiliki pambukuan (Tabel 9). 
Tabel 9

Kepemilikan Pembukuan Usaha

\begin{tabular}{llrrrrrrrrrrr}
\hline No. & $\begin{array}{l}\text { Kepemilikan } \\
\text { Pembukuan }\end{array}$ & \multicolumn{2}{c}{ Malang } & \multicolumn{2}{c}{ Pasuruan } & \multicolumn{2}{c}{ Mojokerto } & Lumajang & \multicolumn{2}{c}{ Total } \\
\cline { 2 - 12 } & & Jml & $\%$ & Jml & $\%$ & Jml & $\%$ & Jml & $\%$ & Jml & $\%$ \\
\hline 1 & Memiliki & 2 & 9.1 & 4 & 25.0 & 3 & 23.1 & 1 & 10.0 & 10 & 16.4 \\
\hline 2 & Tidak & 20 & 90.9 & 12 & 75.0 & 10 & 76.9 & 9 & 90.0 & 51 & 83.6 \\
& memiliki & & & & & & & & & & \\
\hline & Total & 22 & 100,0 & 16 & 100,0 & 13 & 100,0 & 10 & 100,0 & 61 & 100,0 \\
\hline
\end{tabular}

Alasan tidak memiliki catatan keuangan atau pembukuan sederhana, sebagian besar pengusaha sentra UKM (59\%) menganggap tidak perlu, sisanya $13,1 \%$ karena tidak memahami pembukuan dan $11,5 \%$ tidak sempat melakukan penyusunan(Tabel 10).

Tabel

10 Alasan Tidak Memiliki Pembukuan

\begin{tabular}{|c|c|c|c|c|c|c|c|c|c|c|c|}
\hline \multirow[t]{2}{*}{ No. } & \multirow[t]{2}{*}{ Alasan } & \multicolumn{2}{|c|}{ Malang } & \multicolumn{2}{|c|}{ Pasuruan } & \multicolumn{2}{|c|}{ Mojokerto } & \multicolumn{2}{|c|}{ Lumajang } & \multicolumn{2}{|c|}{ Total } \\
\hline & & $\mathrm{Jml}$ & $\%$ & $\mathrm{Jml}$ & $\%$ & $\mathrm{Jml}$ & $\%$ & $\mathrm{Jml}$ & $\%$ & $\mathrm{Jml}$ & $\%$ \\
\hline 1 & $\begin{array}{l}\text { Tidak } \\
\text { memahami } \\
\text { pembukuan }\end{array}$ & 4 & 18.2 & 4 & 25.0 & 0 & - & 0 & - & 8 & 13.1 \\
\hline 2 & $\begin{array}{l}\text { Menganggap } \\
\text { tidak perlu }\end{array}$ & 16 & 72.7 & 5 & 31.3 & 6 & 46.2 & 9 & 90.0 & 36 & 59.0 \\
\hline 3 & $\begin{array}{l}\text { Tidak sempat } \\
\text { menyusun }\end{array}$ & 2 & 9.1 & 3 & 18.8 & 2 & 15.4 & 0 & - & 7 & 11.5 \\
\hline 4 & $\begin{array}{l}\text { Lainnya } \\
\text { (tidak ada) }\end{array}$ & 0 & - & 4 & 25.0 & 5 & 38.5 & 1 & 10.0 & 10 & 16.4 \\
\hline & Total & 22 & 100,0 & 16 & 100,0 & 13 & 100,0 & 10 & 100,0 & 61 & 100,0 \\
\hline
\end{tabular}

Hampir seluruh pengusaha di semua sentra yang menjadi objek penelitian ini tidak memiliki laporan keuangan. Laporan keuangan dimaksud di sini adalah laporan keuangan standar yang terdiri dari neraca, laporan rugi laba serta laporan perubahan modal (Tabel 11). 
Tabel 11

Kepemilikan Laporan Keuangan

\begin{tabular}{lccccccccccc}
\hline No. & $\begin{array}{c}\text { Kepemilikan } \\
\text { Laporan }\end{array}$ & \multicolumn{2}{c}{ Malang } & \multicolumn{2}{c}{ Pasuruan } & \multicolumn{2}{c}{ Mojokerto } & Lumajang & \multicolumn{2}{c}{ Total } \\
\cline { 3 - 12 } & Keuangan & & $\%$ & Jml & $\%$ & Jml & $\%$ & Jml & $\%$ & Jml & $\%$ \\
& & & & & & & & & & & \\
\hline 1 & Punya & 0 & - & 0 & - & 0 & - & 0 & - & 0 & - \\
\hline 2 & Tidak Punya & 22 & 100.0 & 16 & 100.0 & 13 & 100.0 & 10 & 100.0 & 61 & 100.0 \\
\hline & Total & 22 & 100,0 & 16 & 100,0 & 13 & 100,0 & 10 & 100,0 & 61 & 100,0 \\
\hline
\end{tabular}

Ketiadaan laporan keuangan sebagian besar karena menganggap tidak perlu, selebihnya tidak sempat menyusun dan tidak memahami (Tabel 12).

Tabel 12

Alasan Tidak Memiliki Laporan Keuangan

\begin{tabular}{|c|c|c|c|c|c|c|c|c|c|c|c|}
\hline \multirow[t]{2}{*}{ No. } & \multirow[t]{2}{*}{ Alasan } & \multicolumn{2}{|c|}{ Malang } & \multicolumn{2}{|c|}{ Pasuruan } & \multicolumn{2}{|c|}{ Mojokerto } & \multicolumn{2}{|c|}{ Lumajang } & \multicolumn{2}{|c|}{ Total } \\
\hline & & $\mathrm{Jml}$ & $\%$ & $\mathrm{Jml}$ & $\%$ & $\mathrm{Jml}$ & $\%$ & $\mathrm{Jml}$ & $\%$ & $\mathrm{Jml}$ & $\%$ \\
\hline 1 & $\begin{array}{l}\text { Tidak } \\
\text { memahami } \\
\text { laporan } \\
\text { keuangan }\end{array}$ & 0 & - & 1 & 6.3 & 0 & - & 0 & - & 1 & 1.6 \\
\hline 2 & $\begin{array}{l}\text { Menganggap } \\
\text { tidak perlu }\end{array}$ & 22 & 100.0 & 6 & 37.5 & 7 & 53.8 & 9 & 90.0 & 44 & 72.1 \\
\hline 3 & $\begin{array}{l}\text { Tidak sempat } \\
\text { menyusun }\end{array}$ & 0 & - & 5 & 31.3 & 2 & 15.4 & 1 & 10.0 & 8 & 13.1 \\
\hline 4 & $\begin{array}{l}\text { Lainnya } \\
\text { (tidak ada) }\end{array}$ & 0 & - & 4 & 25.0 & 4 & 30.8 & 0 & - & 8 & 13.1 \\
\hline & Total & 22 & 100,0 & 16 & 100,0 & 13 & 100,0 & 10 & 100,0 & 61 & 100,0 \\
\hline
\end{tabular}

Sebagian besar pengusaha di sentra industri kecil yang menjadi sampel penelitian ini menyatakan tidak ada lembaga keuangan yang secara bersama-sama dibentuk oleh pengusaha. Di Malang, Pasuruan dan Mojokerto sebagian besar $(64 \%, 63 \%, 54 \%)$ tidak merasakan adanya lembaga keuangan bersama, sementara di Lumajang, koperasi merupakan satu-satunya lembaga keuangan yang dibentuk pengusaha (Tabel 13). 
Tabel 13

Lembaga keuangan yang Dibentuk Pengusaha

\begin{tabular}{llrrrrrrrrrrr}
\hline \multirow{2}{*}{ No. } & Lembaga & \multicolumn{2}{c}{ Malang } & \multicolumn{2}{c}{ Pasuruan } & \multicolumn{2}{c}{ Mojokerto } & \multicolumn{2}{c}{ Lumajang } & \multicolumn{2}{c}{ Total } \\
\cline { 3 - 13 } & Keuangan & Jml & $\%$ & Jml & $\%$ & Jml & $\%$ & Jml & $\%$ & Jml & $\%$ \\
\hline 1 & Koperasi & 8 & 36.4 & 4 & 25.0 & 4 & 30.8 & 9 & 90.0 & 25 & 41.0 \\
\hline 2 & Arisan & 0 & - & 2 & 12.5 & 2 & 15.4 & 1 & 10.0 & 5 & 8.2 \\
\hline 3 & BMT & 0 & - & 0 & - & 0 & - & 0 & - & 0 & - \\
\hline 4 & Lainnya & 14 & 63.6 & 10 & 62.5 & 7 & 53.8 & 0 & - & 31 & 50.8 \\
& (tidak ada) & & & & & & & & & \\
\hline & Total & 22 & 100,0 & 16 & 100,0 & 13 & 100,0 & 10 & 100,0 & 61 & 100,0 \\
\hline
\end{tabular}

Secara agregat, sebagian besar (62\%) pengusaha seluruh pendanaan usahanya diperoleh dari modal sendiri, sebesar $20 \%$ yang sebagian kecil pendanaan usaha dari hutang, $16 \%$ sebagian besar pendaanaan usaha dari hutang dan hanya $2 \%$ yang seluruh pendanaan usahanya dari hutang (Tabel 14).

Tabel 14

Sumber Pendanaan Usaha UKM

\begin{tabular}{|c|c|c|c|c|c|c|c|c|c|c|c|}
\hline \multirow[t]{2}{*}{ No. } & \multirow{2}{*}{$\begin{array}{l}\text { Sumber } \\
\text { Pendanaan } \\
\text { Usaha }\end{array}$} & \multicolumn{2}{|c|}{ Malang } & \multicolumn{2}{|c|}{ Pasuruan } & \multicolumn{2}{|c|}{ Mojokerto } & \multicolumn{2}{|c|}{ Lumajang } & \multicolumn{2}{|c|}{ Total } \\
\hline & & $\mathrm{Jml}$ & $\%$ & $\mathrm{Jml}$ & $\%$ & $\mathrm{Jml}$ & $\%$ & $\mathrm{Jml}$ & $\%$ & $\mathrm{Jml}$ & $\%$ \\
\hline 1 & $\begin{array}{l}\text { Seluruhnya } \\
\text { dari utang }\end{array}$ & 0 & - & 0 & - & 1 & 7.7 & 0 & - & 1 & 1.6 \\
\hline 2 & $\begin{array}{l}\text { Sebagian } \\
\text { besar dari } \\
\text { utang }\end{array}$ & 0 & - & 4 & 25.0 & 6 & 46.2 & 0 & - & 10 & 16.4 \\
\hline 3 & $\begin{array}{l}\text { Sebagian } \\
\text { kecil dari } \\
\text { utang }\end{array}$ & 2 & 9.1 & 8 & 50.0 & 2 & 15.4 & 0 & - & 12 & 19.7 \\
\hline 4 & $\begin{array}{l}\text { Seluruhnya } \\
\text { dari modal } \\
\text { sendiri }\end{array}$ & 20 & 90.9 & 4 & 25.0 & 4 & 30.8 & 10 & 100.0 & 38 & 62.3 \\
\hline & Total & 22 & 100,0 & 16 & 100,0 & 13 & 100,0 & 10 & 100,0 & 61 & 100,0 \\
\hline
\end{tabular}

Dari sejumlah kecil pengusaha yang menggunakan hutang sebagai sumber pendanaan usaha, sebagian besar sumber hutangnya bukan dari lembaga keuangan tetapi dari supplier. Ini bisa dilihat dari data agregat tabel 15 . 
Tabel 15

Sumber Pendanaan Utang UKM

\begin{tabular}{llrrrrrrrrrrr}
\hline \multirow{2}{*}{$\begin{array}{l}\text { So. } \\
\text { Usaha }\end{array}$} & \multicolumn{2}{c}{ Malang } & \multicolumn{2}{c}{ Pasuruan } & \multicolumn{2}{c}{ Mojokerto } & \multicolumn{2}{c}{ Lumajang } & \multicolumn{2}{c}{ Total } \\
\cline { 2 - 12 } & Jml & $\%$ & & Jml & $\%$ & Jml & $\%$ & Jml & $\%$ & Jml & $\%$ \\
\hline 1 & Bank Umum & 0 & - & 13 & 81.3 & 0 & - & 0 & - & 13 & 21.3 \\
\hline 2 & BPR & 0 & - & 1 & 6.3 & 2 & 15.4 & 0 & - & 3 & 4.9 \\
\hline 3 & Koperasi & 2 & 9.1 & 1 & 6.3 & 1 & 7.7 & 0 & - & 4 & 6.6 \\
\hline 4 & Perusahaan & 0 & - & 0 & - & 3 & 23.1 & 0 & - & 3 & 4.9 \\
& pemerintah/swasta & & & & & & & & & \\
\hline 5 & Lainnya/tidak ada & 20 & 90.9 & 1 & 6.3 & 7 & 53.8 & 10 & 100.0 & 38 & 62.3 \\
\hline & Total & 22 & 100,0 & 16 & 100,0 & 13 & 100,0 & 10 & 100,0 & 61 & 100,0 \\
\hline
\end{tabular}

Sebagian besar pengusaha menyatakan bahwa tidak ada pembinaan keuangan yang menyertai pembiayaan hutang yang dilakukan baik oleh lembaga keuangan bank maupun lembaga keuangan mikro lainnya seperti koperasi (Tabel 16).

Tabel 16

Model Pembinaan dan Pembiayaan Keuangan yang Dilakukan Lembaga Kreditur

\begin{tabular}{|c|c|c|c|c|c|c|c|c|c|c|c|}
\hline \multirow[t]{2}{*}{ No. } & \multirow{2}{*}{$\begin{array}{l}\text { Model } \\
\text { Pembinaan }\end{array}$} & \multicolumn{2}{|c|}{ Malang } & \multicolumn{2}{|c|}{ Pasuruan } & \multicolumn{2}{|c|}{ Mojokerto } & \multicolumn{2}{|c|}{ Lumajang } & \multicolumn{2}{|c|}{ Total } \\
\hline & & $\mathrm{Jml}$ & $\%$ & $\mathrm{Jml}$ & $\%$ & $\mathrm{Jml}$ & $\%$ & $\mathrm{Jml}$ & $\%$ & $\mathrm{Jml}$ & $\%$ \\
\hline 1 & $\begin{array}{l}\text { Pembiayaan } \\
\text { saja }\end{array}$ & 0 & - & 14 & 87.5 & 6 & 46.2 & 0 & - & 20 & 32.8 \\
\hline 2 & $\begin{array}{l}\text { Pembiayaan } \\
\text { dan pelatihan }\end{array}$ & 0 & - & 0 & - & 0 & - & 0 & - & 0 & - \\
\hline 3 & $\begin{array}{l}\text { Pembiayaan, } \\
\text { pelatihan dan } \\
\text { pendampingan }\end{array}$ & 0 & - & 0 & - & 0 & - & 0 & - & 0 & - \\
\hline 4 & Tidak ada & 22 & 100.0 & 2 & 12.5 & 7 & $\overline{53.8}$ & 10 & 100.0 & 41 & 67.2 \\
\hline & Total & 22 & 100,0 & 16 & 100,0 & 13 & 100,0 & 10 & 100,0 & 61 & 100,0 \\
\hline
\end{tabular}

\section{Opini Pengusaha Seputar Permodalan dan Kredit}

Bagian ini mengilustrasikan bagaimana opini pengusaha di sentra UKM tentang modal usaha dan seputar permasalahan kredit. Terkait permasalahan modal, secara agregat, sebagian besar pengusaha menyatakan sangat setuju (44\%) 
dan setuju (26\%) bahwa modal merupakan permasalahan penting dalam pengembangan usaha mereka. Secara terpisah, pengusaha di sentra Malang, Pasuruan dan Mojoketo, sebagian besar setuju bahwa modal merupakan sesuatu yang penting dalam usaha. Sedangkan pengusaha Sentra Kerajinan Perak Lumajang sebagian besar $80 \%$ menyatakan tidak setuju bahwa modal merupakan sesuatu yang sangat utama dalam pengembangan usaha mereka, hanya $20 \%$ yang menyatakan menyetujuinya (Tabel 17).

Tabel 17

Opini Pengusaha tentang Modal

\begin{tabular}{|c|c|c|c|c|c|c|c|c|c|c|c|}
\hline \multirow[t]{2}{*}{ No. } & \multirow[t]{2}{*}{ Opini } & \multicolumn{2}{|c|}{ Malang } & \multicolumn{2}{|c|}{ Pasuruan } & \multicolumn{2}{|c|}{ Mojokerto } & \multicolumn{2}{|c|}{ Lumajang } & \multicolumn{2}{|c|}{ Total } \\
\hline & & $\overline{\mathrm{Jml}}$ & $\%$ & $\mathrm{Jml}$ & $\%$ & $\mathrm{Jml}$ & $\%$ & $\mathrm{Jml}$ & $\%$ & $\mathrm{Jml}$ & $\%$ \\
\hline 1 & Sangat setuju & 17 & 77.3 & 5 & 31.3 & 4 & 30.8 & 1 & 10.0 & 27 & 44.3 \\
\hline 2 & Setuju & 1 & 4.5 & 8 & 50.0 & 6 & 46.2 & 1 & 10.0 & 16 & 26.2 \\
\hline 3 & Ragu-ragu & 0 & 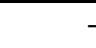 & 0 & - & 0 & - & 0 & - & 0 & - \\
\hline 4 & Tidak setuju & 0 & 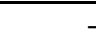 & 1 & 6.3 & 3 & 23.1 & 8 & 80.0 & 12 & 19.7 \\
\hline 5 & $\begin{array}{l}\text { Sangat tidak } \\
\text { setuju }\end{array}$ & 0 & - & 0 & - & 0 & - & 0 & - & 0 & - \\
\hline 6 & Tidak & 4 & 18.2 & 2 & 12.5 & 0 & - & 0 & - & 6 & 9.8 \\
\hline & Menjawab & & & & & & & & & & \\
\hline & Total & 22 & 100,0 & 16 & 100,0 & 13 & 100,0 & 10 & 100,0 & 61 & 100,0 \\
\hline
\end{tabular}

Meskipun sebagian besar pengusaha sepakat bahwa modal merupakan sesuatu yang penting dalam pengembangan usaha, namun tidak semua pengusaha setuju bahwa modal harus diperoleh melalui hutang. Secara agregat nampak opini pengusaha bahwa sebagian besar menyatakan tidak penting bagi pengusaha untuk mencari pendanaan dari hutang (54\% tidak penting dan $2 \%$ sangat tidak penting) dan sebagian kecil menyatakan penting (23\% penting dan $8 \%$ sangat penting) (Tabel 18). 
Tabel 18

Opini Pengusaha tentang Pembiayaan dari Hutang

\begin{tabular}{|c|c|c|c|c|c|c|c|c|c|c|c|}
\hline \multirow[t]{2}{*}{ No. } & \multirow[t]{2}{*}{ Opini } & \multicolumn{2}{|c|}{ Malang } & \multicolumn{2}{|c|}{ Pasuruan } & \multicolumn{2}{|c|}{ Mojokerto } & \multicolumn{2}{|c|}{ Lumajang } & \multicolumn{2}{|c|}{ Total } \\
\hline & & $\mathrm{Jml}$ & $\%$ & $\mathrm{Jml}$ & $\%$ & $\mathrm{Jml}$ & $\%$ & $\mathrm{Jml}$ & $\%$ & $\mathrm{Jml}$ & $\%$ \\
\hline \multirow[t]{2}{*}{1} & Sangat & $\overline{0}$ & - & 2 & 12.5 & 3 & 23.1 & 0 & - & 5 & 8.2 \\
\hline & Penting & & & & & & & & & & \\
\hline 2 & Penting & 5 & 22.7 & 7 & 43.8 & 2 & 15.4 & 0 & - & 14 & 23.0 \\
\hline 3 & Ragu-ragu & 0 & - & 1 & 6.3 & 1 & 7.7 & 0 & - & 2 & 3.3 \\
\hline \multirow[t]{2}{*}{4} & Tidak & 13 & 59.1 & 4 & 25.0 & 7 & 53.8 & 9 & 90.0 & 33 & 54.1 \\
\hline & Penting & & & & & & & & & & \\
\hline \multirow[t]{2}{*}{5} & Sangat Tidak & 0 & - & 0 & - & 0 & - & 1 & 10.0 & 1 & 1.6 \\
\hline & Penting & & & & & & & & & & \\
\hline \multirow[t]{3}{*}{6} & Tidak & 4 & 18.2 & 2 & 12.5 & 0 & - & 0 & - & 6 & 9.8 \\
\hline & manjawab & & & & & & & & & & \\
\hline & Total & 22 & 100,0 & 16 & $\overline{100,0}$ & 13 & 100,0 & 10 & 100,0 & 61 & 100,0 \\
\hline
\end{tabular}

Jika misalkan semua pengusaha membutuhkan hutang untuk meningkatkan modal dalam mengembangkan usaha, perlu kiranya kami digali opini pengusaha terhadap kemudahan dalam perolehan kredit dari lembaga keuangan. Opini pengusaha sentra industri kecil relatif beragam dalam menanggapi masalah ini. Secara agregat nampak opini bahwa sebagian besar pengusaha merasakan mudahnya memperoleh kredit dari lembaga keuangan (34\% menjawab mudah dan 18\% sangat mudah). Sebagian kecil (15\%) yang menyatakan sulit, serta 18\% ragu-ragu (Tabel 19).

Tabel 19

Opini Pengusaha tentang kemudahan memperoleh kredit

\begin{tabular}{llcrrrrrrrrrr}
\hline \multirow{2}{*}{ No. } & Opini & \multicolumn{2}{c}{ Malang } & \multicolumn{2}{c}{ Pasuruan } & \multicolumn{2}{c}{ Mojokerto } & Lumajang & \multicolumn{2}{c}{ Total } \\
\cline { 3 - 12 } & & Jml & $\%$ & Jml & $\%$ & Jml & $\%$ & Jml & $\%$ & Jml & $\%$ \\
\hline 1 & $\begin{array}{l}\text { Sangat } \\
\text { Mudah }\end{array}$ & 5 & 22.7 & 1 & 6.3 & 0 & - & 5 & 50.0 & 11 & 18.0 \\
& & & & & & & & & & & \\
\hline 2 & Mudah & 3 & 13.6 & 8 & 50.0 & 5 & 38.5 & 5 & 50.0 & 21 & 34.4 \\
\hline 3 & Ragu-ragu & 9 & 40.9 & 0 & - & 2 & 15.4 & 0 & - & 11 & 18.0 \\
\hline 4 & Sulit & 1 & 4.5 & 3 & 18.8 & 5 & 38.5 & 0 & - & 9 & 14.8 \\
\hline 5 & Sangat Sulit & 0 & - & 0 & - & 1 & 7.7 & 0 & - & 1 & 1.6 \\
\hline
\end{tabular}




\begin{tabular}{llllllllllll}
\hline 6 & $\begin{array}{l}\text { Tidak } \\
\text { manjawab }\end{array}$ & 4 & 18.2 & 4 & 25.0 & 0 & - & 0 & - & 8 & 13.1 \\
& & & & & & & & & & \\
\hline & Total & 22 & 100,0 & 16 & 100,0 & 13 & 100,0 & 10 & 100,0 & 61 & 100,0 \\
\hline
\end{tabular}

Secara agregat, ketika diminta opini tentang jatuh tempo kredit yang mereka terima atau baru pada tahap ditawarkan oleh lembaga-lembaga keuangan, para pengusaha menyatakan bahwa jatuh tempo kredit yang diterima atau ditawarkan tersebut relatif panjang jatuh temponya (57\% panjang dan $2 \%$ sangat panjang) (Tabel 20)

Tabel 20

Opini Pengusaha tentang Jatuh tempo kredit yang diterima/ditawarkan

\begin{tabular}{|c|c|c|c|c|c|c|c|c|c|c|c|}
\hline \multirow[t]{2}{*}{ No. } & \multirow[t]{2}{*}{ Opini } & \multicolumn{2}{|c|}{ Malang } & \multicolumn{2}{|c|}{ Pasuruan } & \multicolumn{2}{|c|}{ Mojokerto } & \multicolumn{2}{|c|}{ Lumajang } & \multicolumn{2}{|c|}{ Total } \\
\hline & & $\mathrm{Jml}$ & $\%$ & $\mathrm{Jml}$ & $\%$ & $\mathrm{Jml}$ & $\%$ & $\mathrm{Jml}$ & $\%$ & $\mathrm{Jml}$ & $\%$ \\
\hline 1 & $\begin{array}{l}\text { Sangat } \\
\text { panjang }\end{array}$ & 0 & - & 0 & - & 1 & 7.7 & 0 & - & 1 & 1.6 \\
\hline 2 & Panjang & 18 & 81.8 & 5 & 31.3 & 3 & 23.1 & 9 & 90.0 & 35 & 57.4 \\
\hline 3 & Sedang & 0 & - & 5 & 31.3 & 1 & 7.7 & 1 & 10.0 & 7 & 11.5 \\
\hline 4 & Pendek & 0 & - & 1 & 6.3 & 2 & 15.4 & 0 & - & 3 & 4.9 \\
\hline 5 & $\begin{array}{l}\text { Sangat } \\
\text { Pendek }\end{array}$ & 0 & - & 0 & - & 1 & 7.7 & 0 & - & 1 & 1.6 \\
\hline 6 & $\begin{array}{l}\text { Tidak } \\
\text { manjawab }\end{array}$ & 4 & 18.2 & 5 & 31.3 & 5 & 38.5 & 0 & - & 14 & 23.0 \\
\hline & Total & 22 & 100,0 & 16 & 100,0 & 13 & 100,0 & 10 & 100,0 & 61 & 100,0 \\
\hline
\end{tabular}

Namun ketika ditanya lagi tentang apakah jangka waktu kredit tersebut merupakan sesuatu yang cukup penting dalam aplikasi kredit, sebagian besar pengusaha menyatakan penting $56 \%$ dan sangat penting, $18 \%$ dan sisanya tidak menjawab (18\%) dan ragu-ragu (2\%) serta tidak penting (3\%) dan sangat tidak penting $(3 \%)$ (Tabel 21).

Tabel 21

Opini Pengusaha tentang Pentingnya Jatuh Tempo Kredit

\begin{tabular}{|c|c|c|c|c|c|c|c|c|c|c|c|}
\hline \multirow[t]{2}{*}{ No. } & \multirow[t]{2}{*}{ Opini } & \multicolumn{2}{|c|}{ Malang } & \multicolumn{2}{|c|}{ Pasuruan } & \multicolumn{2}{|c|}{ Mojokerto } & \multicolumn{2}{|c|}{ Lumajang } & \multicolumn{2}{|c|}{ Total } \\
\hline & & $\mathrm{Jml}$ & $\%$ & $\overline{\mathrm{Jml}}$ & $\%$ & $\mathrm{Jml}$ & $\%$ & $\mathrm{Jml}$ & $\%$ & $\mathrm{Jml}$ & $\%$ \\
\hline \multirow[t]{2}{*}{1} & Sangat & 0 & - & 3 & 18.8 & 2 & 15.4 & 6 & 60.0 & 11 & 18.0 \\
\hline & Penting & & & & & & & & & & \\
\hline 2 & Penting & 17 & 77.3 & 8 & 50.0 & 5 & 38.5 & 4 & 40.0 & 34 & 55.7 \\
\hline
\end{tabular}




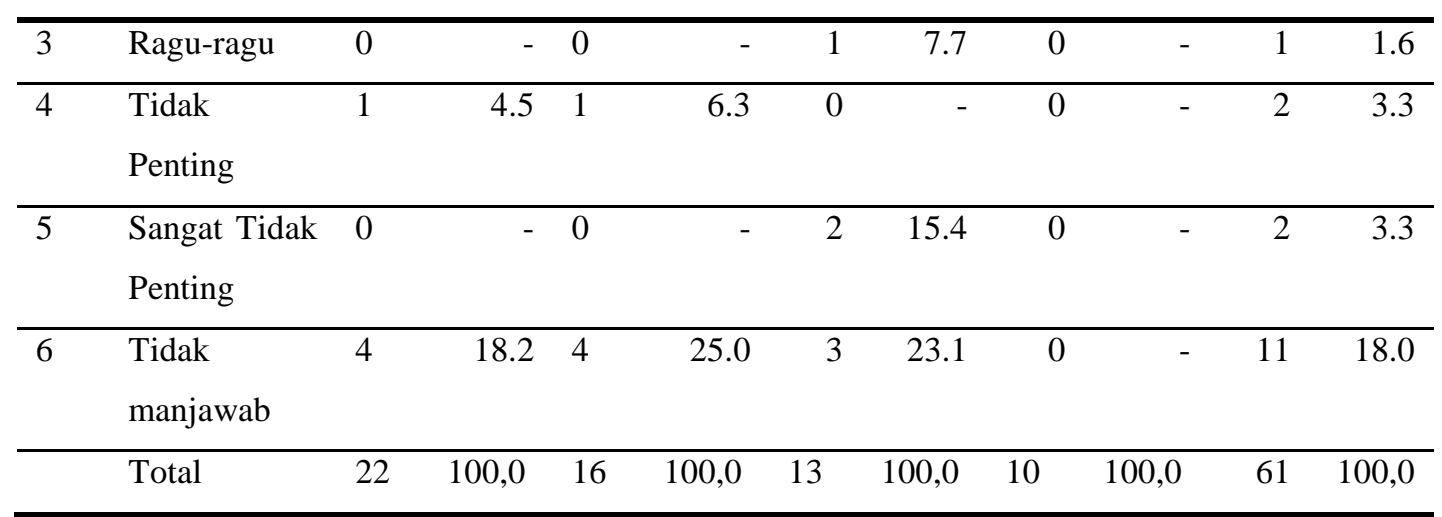

\section{Keberagaman Opini Pengusaha diantara Sentra-sentra UKM}

Untuk melihat apakah terdapat keragaman opini terkait permodalan dan kredit lembaga keuangan, berikut ini disajikan hasil uji beda opini antar sentra yang berbeda.

\section{Tabel 22}

Hasil Uji Beda dengan Menggunakan Kruskal Wallis

\begin{tabular}{llll}
\hline No & Opini Pengusaha & Asymp. Sig. & Kesimpulan \\
\hline 1 & Pentingnya Modal & 0,000 & Terdapat perbedaan opini antar sentra \\
\hline 2 & Pembiayaan dari Hutang & 0,003 & Terdapat perbedaan opini antar sentra \\
\hline 3 & kemudahan memperoleh & 0,004 & Terdapat perbedaan opini antar sentra \\
& kredit & & \\
\hline 4 & Jatuh tempo kredit yang & 0,005 & Terdapat perbedaan opini antar sentra \\
& diterima/ditawarkan & & Terdapat perbedaan opini antar sentra \\
\hline 5 & Pentingnya Jatuh Tempo & 0,005 & \\
& Kredit & & \\
\hline
\end{tabular}

Berdasarkan hasil uji Kruskal Wallis diperoleh bahwa terjadi keragaman pendapat/opini antar pengusaha di sentra yang berbeda. Hal ini mengindikasikan bahwa diantara sentra yang memiliki karakteristik berbeda akan memunculkan opini yang berbeda atas permodalan dan kredit lembaga keuangan yang ditawarkan. Sentra industri tempe memiliki karakteristik yang sangat berbeda dengan sentra yang lain baik dalam hal jadwal produksi, frekuensi transaksi, skala produksi dan sebagainya. Begitu pula dengan karakteristik usaha kerajinan perak Lumajang, 


\section{PEMBAHASAN}

Berdasarkan jumlah aset, omset tahunan dan jumlah tenaga kerja, perusahaan-perusahaan di sentra UKM yang menjadi sampel penelitian ini, disimpulkan bahwa sebagian besar pengusaha di sentra-sentra UKM merupakan pengusaha kecil, dan sebagian kecil merupakan pengusaha menengah. Sebagaimana dinyatakan dalam Pasal 5 Undang-undang No. 9 Tahun 1995 tentang Usaha Kecil, bahwa usaha yang termasuk dalam usaha kecil diantaranya memiliki aset bersih maksimal 200 juta tidak termasuk tanah dan bangunan, omset tahunan maksimal Rp1 miliar, dan status perorangan.

Sebagian besar perusahaan di sentra UKM dikelola secara sederhana dan bersifat konvensional, khususnya dalam hal pengelolaan keuangan. Sedikit sekali pengusaha yang memiliki pembukuan sederhana dan hampir tidak ada pengusaha yang memiliki laporan keuangan. Para pengusaha berlasan : a) masih kecilnya skala usaha yang mereka lakukan sehingga belum merasa perlu untuk melakukan itu; b) karena tidak memahami pembukuan dan laporan keuangan; dan c) pengusaha tidak harus mempertanggungjawabkan kinerjanya pada pihak manapun. Yang terpenting, menurut mereka, keuntungan yang diperoleh setelah dikurangi kebutuhan sehari-hari dapat digunakan untuk membeli bahan-bahan untuk proses produksi. Alasan ini nampak dalam tabel 10 dan 11.

Kendala yang dihadapi pengusaha cenderung beragam antara kendala keuangan, pemasaran dan produksi. Permasalahan modal bagi pengusaha ternyata bukanlah satu-satuhnya faktor penting dalam pengembangan usaha mereka. Kondisi usaha kerajinan perak yang masuk dalam siklus kejenuhan pasar dan likuiditas pengusaha masih tinggi salah satu penyebab munculnya opini ini. Kondisi ini tidak terlepas dari karakteristik sentra yang beragam baik dari sisi trend produk dan penjualan serta siklus usaha. Sentra yang dalam siklus naik sangat membutuhkan modal dan sentra yang dalam siklus menurun lebih membutuhkan pemasaran.

Permasalahan keuangan juga cenderung beragamn diantara sentra yang berbeda. Sebagian besar pengusaha kecil menggunakan modal sendiri untuk membiayai usahanya. Penggunaan modal sendiri yang dominan dikarenakan akses ke perbankan relatif sulit akibat pengelolaan keuangan yang lemah. Kondisi ini 
diperparah dengan tidak ada pembinaan keuangan yang dilakukan baik oleh lembaga keuangan bank maupun lembaga keuangan mikro lainnya seperti koperasi. Pembinaan keuangan bersifat tidak langsung berupa monitoring atas angsuran kredit yang dilakukan debitur.

Terkait dengan lembaga keuangan yang dibentuk pengusaha secara bersama-sama yang diharapkan dapat melayani kebutuhan pendanaan, para pengusaha sebagian belum merasakan keberadaan lembaga tersebut secara maksimal. Dalam beberapa wawancara dengan pihak terkait diperoleh informasi bahwa telah ada suatu skema permodalan bagi UKM di sentra-sentra UKM yang disebut Model MAP (Modal Awal Padanan).

Pandangan pengusaha atas pentingnya modal, hutang, jatuh tempo, kemudahan memperoleh kredit juga relatif beragam diantara sentra-sentra berbeda. Namun demikian dapat disimpulkan suatu kesamaan dimana sentra dengan kapasitas produksi yang besar lebih merasa berkepentingan atas modal dibandingkan sentra dengan kapasitas rendah.

\section{KESIMPULAN DAN SARAN}

\section{Kesimpulan}

Dari hasil data yang diperoleh, berdasarkan observasi dan wawancara terhadap para pengusaha dan pihak-pihak yang terkait di sentra-sentra UKM, diperoleh beberapa kesimpulan bahwa: 1) pembiayaan dalam bentuk pinjaman modal bukanlah sesuatu yang mutlak diperlukan oleh para pengusaha di sentra UKM. Pembiayaan untuk pengusaha bisa dalam bentuk barang modal yang biasanya disediakan oleh suplier dan pelanggan, yang terpenting bagi para pengusaha kecil adalah bagaimana memperluas pangsa pasar dan meningkatkan volume penjualan, karena jika permintaan produk mereka meningkat, cukup mudah bagi pengusaha untuk memperoleh pinjaman; 3) model pembiayaan dan pembinaan keuangan oleh lembaga keuangan yang khas bagi pengusaha kecil di sentra-sentra industri kecil adalah Model MAP (Modal Awal Padanan) yang merupakan implementasi program P2LK-MAP (Perkuatan Permodalan dan Lembaga Keuangannya melalui penyediaan Modal Awal dan Padanan), yakni 
program Kementerian Negara Koperasi dan Usaha Kecil Menengah yang dirancang khusus untuk mengembangkan permodalan pengusaha di sentra UKM.

\section{Saran}

Pengusaha di sentra-sentra UKM hendaknya melakukan pencatatan keuangan dan memisahkannya dengan keuangan keluarga sebagai fondasi bagi terbentuknya pengelolaan usaha yang lebih modern dan profesional dan sebagai dasar terbentuknya kemajuan usaha. Lembaga-lembaga kreditur pada pengusaha di sentra UKM hendaknya lebih memperhatikan kebutuhan riil pengusaha (needbased program) dalam melakukan pembiayaan. Pemerintah hendaknya lebih fokus pada proses penyadaran pada pengusaha tentang perlunya profesionalitas dalam berusaha dan pengelolaan bisnis modern. Peneliti lebih lanjut hendaknya memfokuskan diri pada populasi yang relatif lebih homogen untuk mempermudah generalisasi. Penelitian lebih lanjut atas efektivitas pelaksanaan program P2LKMAP sangat direkomendasikan untuk menindaklanjuti temuan ini.

\section{DAFTAR RUJUKAN}

Anonimous. 2005. Background Paper on Microfinance Policy and Strategy. Promotion of Small Financial Institution-ProFI. Version 2.1 07.

Anonimous. Undang-undang No 9 Tahun 1995 tentang Usaha Kecil

Anonimous. Undang-undang No. 7 Tahun 1992 yang telah diamandemen dengan Undang-Undang No. 10 Tahun 1998Tentang Perbankan

Anonimous. Koperasi di Sentra Industri Minim. Htpp/www.surya.co.id. Surya Online 5 Maret 2007

Anonimous. Keputusan Menteri Keuangan No. 40/KMK/.06/2003 tanggal 29 Januari 2003 tentang Pendanaan Kredit usaha Mikro dan Kecil.

Anonimous. Instruksi Presiden RI No. 10 Tahun 1999 tentang Pemberdayaan Usaha Menengah)

Armendariz de Aghion. Beatriz dan Jonathan Morduch. 2005. The Economics of Microfinance. Cambridge. MA: MIT Press. 
Anonimous. 2006. Evalasi Program Bantuan Dana Bergulir Melalui KSP/USP Koperasi (Pola PKPS-BBM, Agribisnis dan Syariah). Jurnal Pengkajian Koperasi dan UKM. Nomor 1 Tahun I.

Abduddin, A. 2006. Pengkajian Dukungan Financial dan Non Financial dalam Pengembangan Sentra Bisnis UKM. Jurnal Pengkajian Koperasi dan UKM. Nomor 1 Tahun I.

Moleong, Lexy. 2001. Metodologi Penelitian Kualitatif, Bandung: Remaja Rosda Karya.

Morduch, J dan Stuart Rutherford. 2003. Microfinance: analytical issues for India.Oxford University Press.

Panggabean, R. 2005. Efektivitas Program Dana Bergulir bagi Koperasi dan UKM, Jurnal Infokop. No 26 Tahun XX

Siamat, D. 2006. Manajemen Lembaga Keuangan, Edisi Kelima, Lembaga Penerbit FEUI

Sutrisno dan Sri Lestari, 2006. Kajian Usaha Mikro Indonesia, Jurnal Pengkajian Koperasi dan UKM. No. 2 Tahun I.

Vondelack, R M and Mark Schreiner. 2001. Women, Micrfinance and Savings : Lesson and proposals.

Yunus, M. 2007. Bank Kaum Muskin. Tangerang: Penerbit Marjin Kiri.

Conroy, J. D. 2000. The Role of Central Bank in Microfinance in Asian and Pasific. 